\title{
ANALISIS MODUS PADA TINDAK TUTUR MEME DALAM AKUN DAGELAN DI INSTAGRAM
}

\author{
The Speech Act of Memes on Dagelan's Instagram Account
}

\author{
Benny Mega Wati, Rina Marnita \\ Program Studi Linguistik Universitas Andalas, Padang, Indonesia \\ e-mail: bennymegawati@yahoo.com
}

(Masuk: 9 Oktober 2019, diterima: 30 April 2020)

\begin{abstract}
Abstrak
Penelitian ini merupakan penelitian deskriptif kualitatif. Objek penelitian ini adalah tagar pada meme yang diunggah di akun@dagelan di Instagram. Tagar qurbaninaja (\#qurbaninaja) muncul bersamaan dengan perayaan hari raya Iduladha yang pernah menjadi topik teratas di media sosial. Tagar qurbaninaja dipilih karena pesan sosialnya sangat dalam. Melalui tagar qurbaninaja, pengguna Instagram dapat menyampaikan dan menerima tuturan terkait dengan fenomena berkurban. Tujuan penelitian ini untuk menemukan jenis tindak tutur berdasarkan modus yang digunakan dalam \#qurbaninaja yang diunggah akun@dagelan. Penelitian ini menggunakan teori yang dikemukakan oleh Wijana (1996) untuk menemukan jenis tuturan dalam meme berdasarkan modus yang dipakai. Penelitian ini menggunakan metode simak dengan teknik simak bebas libat cakap (SBLC) dan teknik catat, karena peneliti tidak terlibat langsung dalam proses pembuatan data. Hasil dari penelitian menemukan bentuk satir yang digunakan untuk mengungkapkan sindiran yang tersembunyi dari setiap meme yang diunggah. Dari beberapa meme yang diambil, modus yang muncul berbentuk deklaratif dan interogatif dengan jenis tindak tutur langsung, tindak tutur tidak langsung, dan tutur tidak literal.
\end{abstract}

Kata kunci: Tindak Tutur, Meme, Instagram

\begin{abstract}
Abstact
This research is a descriptive qualitative research. The object of this research is the hashtag on the meme uploaded on the Instagram account@dagelan.The hashtag qurbaninaja (\#qurbaninaja) appeared along with the celebration of Iduladha which was once the top topic on social media. \#Qurbaninaja was chosen because the social message of the hashtag was very deep. Through \#qurbaninaja, Instagram users can deliver and receive speeches related to the phenomenon of sacrifice. The purpose of this study is to find the type of speech acts through the mode used in \#qurbaninaja uploaded by@dagelan account. To analyse the type of speech acts in memes the writer uses Wijana's theory (1966). The type of speeh acts is classified according to its modus. And uses the Simak method with SBLC techniques and the Record technique because the researcher is not directly involved in the process of creating data. The result of the analysis is found in form of satire. Satire is an expression that is used to express the implisit insinuation in each meme that uploaded. Of the several memes taken, the mode that emerges is declarative and interrogative with the types of direct speech acts, indirect speech acts, and non-literal speeches.
\end{abstract}

Keywords: Speech Acts, Meme, Instagram 


\section{PENDAHULUAN}

Meme adalah gambar yang diberi teks. Meme pertama kali diperkenalkan oleh Richard Dawkins pada tahun 1970 dalam Jabbar (2016). Menurut Dawkins, meme adalah sebuah ide kepercayaan atau sebuah ide yang menyebar dari satu atau banyak orang kepada orang yang lain. Meme diciptakan melalui proses pengulangan gambar yang diambil dari sumber terpercaya dan memodifikasinya. Meme tersebut berasal dari para fotografer yang banyak tersedia di mesin google. Sang kreator hanya perlu menambahkan dan mengurangi teks, atau dengan menambahkan gambar lain, tergantung selera dari sang kreator.

Dalam situs Merdeka.com disebutkan bahwa gambar yang disebut meme sebenarnya adalah bentuk ekspresi seseorang yang ditumpahkan lewat gambar-gambar. Menurut Bauckhage (2011) dalam Nugraha, meme biasanya berkembang melalui komentar, imitasi, parodi, atau bahkan hasil pemberitaan di media. Menurut Shifman (2013) dalam Nugraha, frasa meme umumnya diterapkan untuk menggambarkan propaganda pada konten seperti lelucon, rumor, video, atau situs dari satu orang ke orang lainnya melalui internet.

Penelitian yang dilakukan oleh Nugraha (2015) menjelaskan bahwa meme bisa menyebar dalam bentuk aslinya, tetapi sering juga memunculkan turunan atau pembaharuan yang dibuat pengguna. Apabila merasa tertarik dengan topik dan gambar meme yang dilihat dalam suatu media sosial, pengguna akan melakukan reposting atau mengunggah kembali posting meme tersebut ke dalam akun pribadinya. Oleh karena itu, banyak jenis dan bentuk meme yang menyebar tidak hanya di kalangan pengguna media sosial saja tetapi juga sudah mulai meluas di kalangan masyarakat.

Media sosial merupakan sebuah jembatan penghubung yang digunakan untuk berkomunikasi di jejaring sosial. Di Indonesia, media sosial mulai populer sejak munculnya Friendster pada tahun 2007. Sampai saat ini media sosial banyak bermunculan dengan fitur yang lebih bervariasi dan lengkap, seperti twitter, facebook, path, instagram, dan tumblr. Saat ini media sosial yang banyak diminati adalah Instagram. Instagram dianggap sebagai media sosial yang paling lengkap oleh para remaja. Media sosial ini lebih berfokus pada foto dan video yang berdurasi pendek, sedangkan media sosial yang lain berfokus pada kicauan, perkataan, atau status. Jadi peneliti melihat bahwa Instagram merupakan salah satu media sosial yang cocok untuk mengunggah meme dan mudah digunakan atau dinikmati.

Pengguna Instagram terdiri atas berbagai lapisan masyarakat, misalnya artis lokal mancanegara, klub olahraga internasional, dan masyarakat biasa. Mereka memiliki akun sendiri dan aktifmembagikan kegiatan harian mereka. Melalui Instagram itulah, para penggemar dapat mengetahui kegiatan idolanya melalui foto dan video yang diunggah (Mahendra, 2017).

Salah satu akun dalam Instagram yang sering berbagi meme adalah akun@dagelan. Akun ini merupakan sebuah akun dengan konten komedi yang memiliki banyak pengikut. Saat ini pengikut dari@dagelan sudah mencapai 13,6 juta orang. @dagelan dalam Kamus Besar Bahasa Indonesia (daring) memiliki arti melucu (berjenaka, melawak, dan sebagainya) untuk membuat orang tertawa. Akun@dagelan merupakan salah satu akun dalam media sosial yang disenangi banyak orang dengan menampilkan berbagai macam gaya bahasa.Dalam akun@dagelan banyak memememe yang mengutarakan perasaan yang mengandung tuturan-tuturan yang nyeleneh dan berdasarkan fakta. Tuturan-tuturan tersebut terangkai dengan unggahan foto yang diberi teks.

Meme dalam Instagram banyak dibubuhi tanda pagar atau tagar. Tagar disematkan di dalam dan juga di bagian luar gambar. Tagar merupakan sebuah tanda yang digunakan untuk menandai sebuah label secara spesifik. Label bisa berupa kata atau kalimat tanpa spasi yang awalannya diberi tagar. Tagar tersebut menjadi penghubung dalam mencari pesan khusus terhadap tema yang ditandai tagar tersebut 
(http://repository.uksw.edu/). Tagar merupakan jalan masuk bagi pengguna media sosial untuk menemukan suatu komunitas, tema postingan, rujukan maupun suatu kelompok tertentu. Hal ini untuk meningkatkan intensitas tentang topik yang dimaksud. Salah satu contoh tagar yang ada dalam media sosial Instagram adalah tagar qurbaninaja (\#qurbaninaja).

Tuturan-tuturan yang dikicaukan melalui meme tersebut banyak mendapatkan komentar dari para pengikut akun dagelan. Tidak hanya kolom komentar yang tersedia, likes (tanda suka) juga disediakan untuk melihat seberapa banyak yang menyukai meme, foto, atau video yang sudah dibagikan. Panggilan video juga disediakan untuk melakukan komunikasi langsung dengan pengguna lain.

Tindak tutur merupakan dasar dalam berkomunikasi. Komunikasi dapat dilakukan dengan berbagai cara ke berbagai belahan dunia, salah satunya melalui media sosial. Media sosial diciptakan untuk mengomunikasikan dan berbagi informasi dengan cepat secara daring. Tidak hanya berkomunikasi dan berbagi informasi media sosial juga bisa dimanfaatkan untuk keperluan duniawi seperti mempermudah berkirim kabar, gambar, dan lain-lain. Komunikasi melalui media sosial adalah salah satu cara berkomunikasi yang dapat dilakukan dari jarak jauh dan instan.

Rumusan masalah dalam penelitian ini adalah apa jenis tindak tutur yang digunakan dalam meme yang menggunakan tagar qurbaninaja yang dilihat melalui modus yang digunakan. Adapun tujuan penelitian adalah untuk menjawab rumusan masalah dengan menemukan jenis tuturan yang digunakan dalam meme yang menggunakan tagar qurbaninaja berdasarkan modus yang dipakai.

Sebuah penelitian diharapkan menghasilkan sesuatu yang bermanfaat secara teoretis dan praktis. Secara teoretis penelitian ini diharapkan dapat menambah pengetahuan dan wawasan dalam kajian pragmatik, terutama pada kajian tindak tutur. Selain itu, penelitian ini diharapkan menjadi salah satu rujukan dan referensi untuk peneliti linguistik yang berminat meneliti penggunaan tindak tutur.
Di samping itu, secara praktis penelitian ini memberikan informasi kepada masyarakat ataupun pembaca tentang penggunaan dan makna tagar.Pengguna tagar hendaknya mampu menempatkan konteks dan situasi ketika menggunakannya.Secara praktis, penelitian ini diharapkan bermanfaat memberikan sesuatu yang baru tentang tindak tutur yang digunakan dalam tagar qurbaninaja pada akun@dagelan di Instagram. Penelitian ini dapat dimanfaatkan sebagai bahan pertimbangan dalam diskusi, pendidikan, dan pengayaan materi pragmatik, khususnya tindak tutur dalam tagar qurbaninaja dalam akun@dagelan di Instagram.

Teori yang digunakan untuk memecahkan masalah yang ada dalam penelitian ini adalah teori Wijana (1996). Secara formal, berdasarkan modusnya Wijana (1996) membedakan tuturan menjadi tiga yakni, tuturan bermodus deklaratif, modus introgatif, dan modus imperatif. Ada delapan jenis tindak tutur yang dikemukakan oleh Wijana yakni; (1) Tindak tutur langsung (direct speech), (2) Tindak tutur tidak langsung (indirect speech), (3) Tindak tutur literal (literal speech act), (4) Tindak tutur tidak literal (nonliteral speech act), (5) Tindak tutur langsung literal (direct literal speech), (6) Tindak tutur tidak langsung literal (indirect literal speech act), (7) Tindak tutur langsung tidak literal (direct nonliteral speech), (8) Tindak tutur tidak langsung tidak literal (indirect nonliteral speech act). Di dalam pembahasan, sebelum menemukan jenis tindak tutur dalam meme yang diunggah oleh akun dagelan, terlebih dahulu ditentukan modus yang digunakan.

Sindiran yang digunakan meme dalam akun dagelan di Instagram tidak selalu sama. Ada yang menggunakan sindiran halus tetapi memiliki makna yang bertentangan dan ada yang berbentuk ungkapan dengan maksud menertawakan. Keraf(2007:143) berpendapat bahwa sindiran atau ironi adalah suatu acuan yang ingin mengatakan sesuatudengan makna atau maksud berlainan dari apa yang dimaksudkan. Ada beberapa bentuk sindiran yaitu: sinisme, ironi, innuendo, antifrasis, sarkasme, dan satire. 
Keraf (2007:447) berpendapat bahwa sinisme adalah gaya bahasa sebagai suatu sindiran yang berbentuk kesangsian yang mengandung ejekan terhadap keikhlasan dan ketulusan hati. Ironi adalah gaya bahasa yang berupa sindiran halus yang berupa pernyataan yang maknanya bertentangan dengan makna yang sebenarnya. Sarkasme adalah acuan yang lebih kasar dari ironi yang mengandung kepahitan dan celaan yang getir. Satire adalah gaya bahasa yang berbentuk ungkapan dengan maksud menertawakan dan menolak sesuatu. Innuendo adalah gaya bahasa sindiran yang diungkapkan secara tidak langsung untuk mengatakan yang sebenarnya terjadi. Antifrasis adalah gaya bahasa yang berupa penggunaan sebuah kata dengan maksud kebalikannya.

Sebuah penelitian yang sama-sama terkait adalah Afriyanti (2015) tentang tindak tutur pengajar bimbel Ganesha Operation (GO) Sumatera Barat dalam status facebook. Dalam penelitiannya, Afrianti membahas beberapa kajian, yaitu bentuk kalimat yang digunakan dalam tindak tutur pengajar bimbel GO, jenis tindak tutur pengajar GO Sumatera Barat, dan fungsi tindak tutur pengajar GO Sumatera Barat. Afriyanti menggunakan teori Alwi (2003: 351) untuk mendiskripsikan bentuk tuturan pengajar GO Sumatera Barat. Teori Searle (1969) digunakan untuk mendeskripsikan fungsi tindak tutur pengajar GO Sumatera Barat. Teori Wijana tentang jenis tindak tutur digunakan untuk mendiskripsikan jenis-jenis tindak tutur.

Beberapa kesimpulan yang didapatkan dalam status facebook pengajar GO Sumatera Barat, di antaranya banyak menggunakan kalimat deklaratif karena pengajar GO terbiasa memberi informasi kepada siswa. Afrianti juga menemukan jenis tuturan literal yang banyak digunakan oleh pengajar bimbel GO. Sementara itu fungsi tuturan yang dominan digunakan adalah representatif atau asertif paling banyak digunakan.

Metode pengumpulan data yang digunakan adalah metode simak, sedangkan teknik yang digunakan adalah teknik catat, dan teknik wawancara. Selanjutnya, penganalisisan data dilakukan dengan menggunakan metode padan.

Pada tahap penyajian hasil analisis data, Afrianti melakukan beberapa langkah. Pertama, data asli dipangkas, kemudian diketik ulang dan ditransliterasi ke dalam bahasa Indonesia. Kedua, dipaparkan konteks tuturan tindak tutur pengajar GO. Langkah yang ketiga, hasil analisis dipaparkan dengan memilih data berdasarkan bentuk, fungsi, dan jenis.

Kesamaan yang terlihat dari penelitian yang dilakukan oleh Afriyanti yaitu sama-sama menggunakan teori Wijana untuk melihat jenis tindak tutur yang digunakan. Data juga bersumber dari media sosial. Perbedaan dalam keduanya terletak pada media sosial yang dipakai. Afriyanti (2015) menggunakan tuturan yang ada dalam media sosial facebook, sedangkan penelitian ini menggunakan meme yang diunggah oleh akun dagelan dalam media sosial Instagram.

\section{METODE}

Penelitian ini merupakan penelitian kualitatif menggunakan metode deskriptif. Moleong (2010) mengemukakan bahwa penelitian kualitatif adalah penelitian yang bertujuan untuk memahami fenomena tentang apa yang dialami oleh subjek penelitian, seperti perilaku, persepsi, dan tindakan. Bidang yang dikaji merupakan salah satu bagian dari kajian pragmatik, yaitu tindak tutur.Tindak tutur yang dimaksud adalah meme yang mengandung tagar qurbaninaja dalam akun@dagelan pada Instagram. Penelitian deskriptifini memberikan gambaran penelitian yang objektif tentang keadaan yang sebenarnya dari objek yang diteliti yaitu gambaran yang ada pada meme yang diunggah oleh akun@dagelan di Instagram.

Sudaryanto (1993) mengatakan sumber data terdiri atas 2 jenis, yaitu: sumber lokasional dan sumber substansial. Sumber lokasional 
adalah sumber data yang berhubungan dengan asal data penelitian yang diperoleh oleh peneliti. Sumber data pada penelitian ini diambil dari meme yang menggunakan tagar qurbaninaja dalam akun@dagelan di Instagram. Sumber data substantif adalah bahan mentah data yang berbentuk konkrit. Bentuk konkrit data dalam penelitian ini adalah tulisan atau meme yang mengandung tagar qurbaninaja yang ada dalam akun@dagelan itu sendiri yang berasal dari tangkapan layar atau screen shoot dari pemilik akun Instagram.

Prosedur penyediaan data berawal dengan mengikuti akunnya@dagelan dan memilih meme yang menggunakan tagar qurbaninaja yang diunggah oleh akun tersebut.

Instrumen yang digunakan selama pengumpulan data yaitu handphone. Handphone digunakan peneliti untuk menangkap gambar dan memperhatikan meme yang diunggah oleh akun dagelan selama pengamatan berlangsung. Notebook digunakan untuk menampung dan mengolah data yang digunakan.

Teknik yang dipakai dalam mengumpulkan data adalah teknik Simak Bebas Libat Cakap atau teknik SBLC. Teknik SBLC dipakai karena peneliti tidak terlibat dalam percakapan yang ada pada akun@dagelan yang memakai tagar qurbaninaja. Peneliti hanya sebagai pemerhati pemakaian tagar qurbaninaja dalam akun Instagram pada@dagelan tersebut. Teknik lanjutan untuk membantu teknik sebelumnya adalah teknik catat.

Penggunaan teknik catat yang digunakan pada penelitian ini berbeda dengan teknik catat pada umumnya. Teknik mencatat dokumen dipilih karena sumber data dalam penelitian ini berupa tuturan yang mengandung meme tagar qurbaninaja. Teknik ini dilakukan dengan pertimbangan, antara lain; (1) menghindari hilangnya meme karena sudah dihapus; (2) menghindari terjadinya kehilangan data yang tersimpan dalam ponsel dan menyimpannya dalam laptop.
Analisis data dalam penelitian ini menggunakan metode padan. Metode padan adalah metode analisis data yang alat penentunya berada di luar, terlepas dan tidak menjadi bagian dari bahasa yang bersangkutan atau yang diteliti, Sudaryanto, (1993).

Kegiatan analisis data dilakukan dengan beberapa tahapan sebagai berikut.

No Tahapannya yang dilakuan adalah:

1. memindahkan data ke dalam program Microsoft word

2. memahami setiap data sesuai dengan konteksnya

3. mengklasifikasi data berupa, jenis, fungsi dan makna yang terkandung dalam tagar qurbaninaja dalam akun@dagelan di Instagram dan selanjutnya dimasukkan ke dalam suatu daftar;dan

4. melakukan analisis dengan melihat data dari segi bentuk, jenis, dan fungsi tagar tersebut

5. Setelah data dianalisis dibuat
simpulan.

\section{HASIL DAN PEMBAHASAN}

Hasil dan pembahasan akan dijelaskan secara bersamaan berdasarkan rumusan masalah. Penjelasan dimulai dengan menampilkan foto, kemudian ditentukan tanda lingual dan nonlingual. Setelah menemukan tanda lingual yang ada dalam meme, selanjutnya dijelaskan konteks. Hal itu dilakukan sebelum menjelaskan modus yang digunakan dalam meme tersebut. Setelah menemukan modus yang digunakan dijelaskan jenis yang dipakai oleh pengguna dalam meme tersebut. 


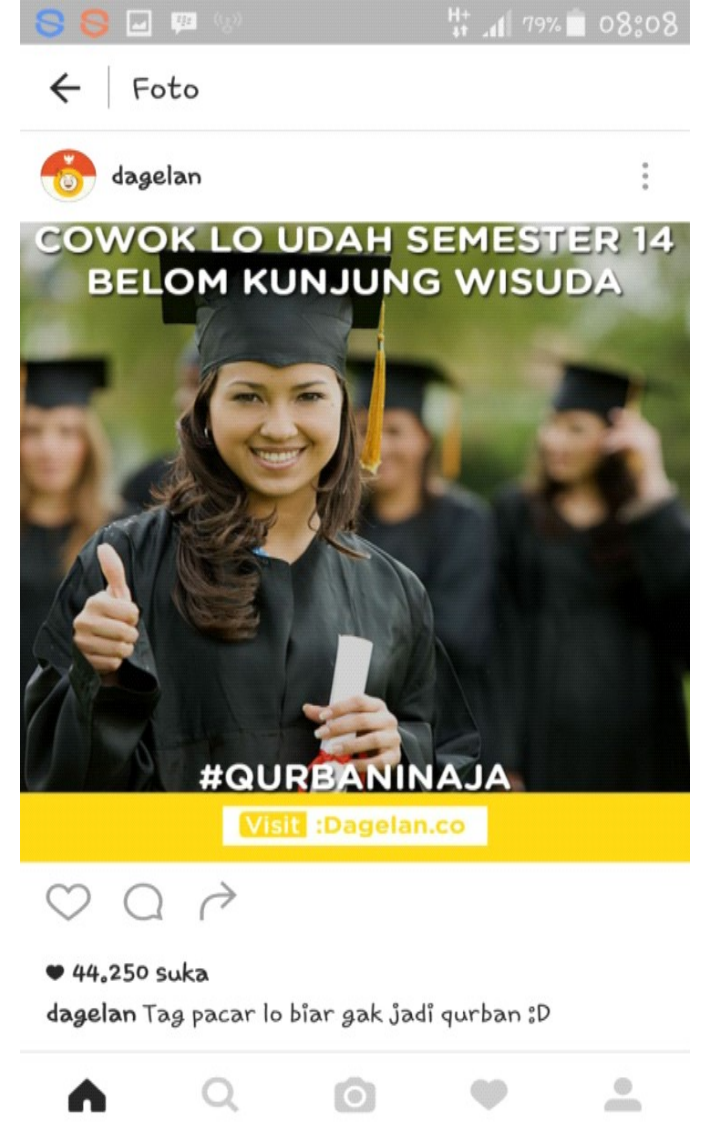

\section{Gambar 1 Meme dalam Akun@dagelan} adalah:

Tanda lingual terdapat dalam meme pada

(1) COWOK LO UDAH SEMESTER 14 BELOM KUNJUNG WISUDA

(2) \#QURBANINAJA

(3) Visit:@dagelan.co

(4) e\&44.250 suka

(5)@dagelan Tag pacar lo biar gak jadi qurban :D

Berdasarkan meme pada gambar (1), ditemukan tanda nonlingual untuk melengkapi tanda-tanda lingual dalam meme tersebut, yaitu: foto seorang perempuan yang sedang tersenyum di acara wisuda sembari mengacungkan jempol.

Konteks gambar (1) dalam meme bertujuan untuk menyindir para pengikut yang mempunyai pacar atau teman dekat yang belum juga kunjung wisuda di semester 14. Konteks iklan tersebut sangat singkat yang dapat membuat para pengikut merasa cemburu. Acungan jempol dari perempuan menambah kesan kebahagiaan sambil memegang sebuah kertas. Perempuan dalam meme berada di antara para wisudawan lainnya.

Tuturan COWOK LO UDAH SEMESTER 14 BELOM KUNJUNG WISUDA 'pacar kamu sudah semester 14, belum juga wisuda', termasuk modus interogatif. Kalimat interogatif disebut juga dengan kalimat tanya. Cowok dalam KBBI daring adalah sebutan kepada para laki-laki yang biasanya masih muda. Pada gambar (1) kata cowok adalah panggilan untuk pasangan lakilaki. Pasangan dari seorang perempuan dinamai dengan cowok. Cowok dalam konteks ini adalah pasangan laki-laki dari seorang perempuan yang belum wisuda.

Kata belum pada gambar (1) merupakan kata penjelas yang dituliskan tanpa menyertakan tanda tanya. Kata belum dalam KBBI daring adalah sebuah keterangan yang berarti masih dalam keadaan tidak. Kata belum menunjukkan sebuah modus interogatif yang dibuat oleh pemilik akun@dagelan.Kata tidak dalam hal ini memiliki makna belum. Artinya adalah belum akan wisuda, tetapi sudah hampir melewati masa perkuliahan. Berdasarkan modusnya tuturan tersebut adalah kalimat interogatif dan esensinya adalah menyuruh. Jenis tindakan yang digunakan adalah tindak tutur tidak langsung. Suruhan yang ditujukan bagi pasangan para perempuan yang sudah berada pada limit akhir dimasa perkuliahannya.

Meme bernada satire yang dibagikan oleh akun dagelan untuk mahasiswa laki-laki yang sudah berada pada tingkat akhir. 'COWOK LO' cowok adalah sebutan untuk seorang lakilaki dan lo adalah sebutan untuk kamu, dalam hal ini kamu adalah perempuan. Pesan yang disampaikan untuk si perempuan menjadikan kurban (tinggalkan) saja laki-laki yang tidak mampu untuk menyelesaikan kuliahnya. 


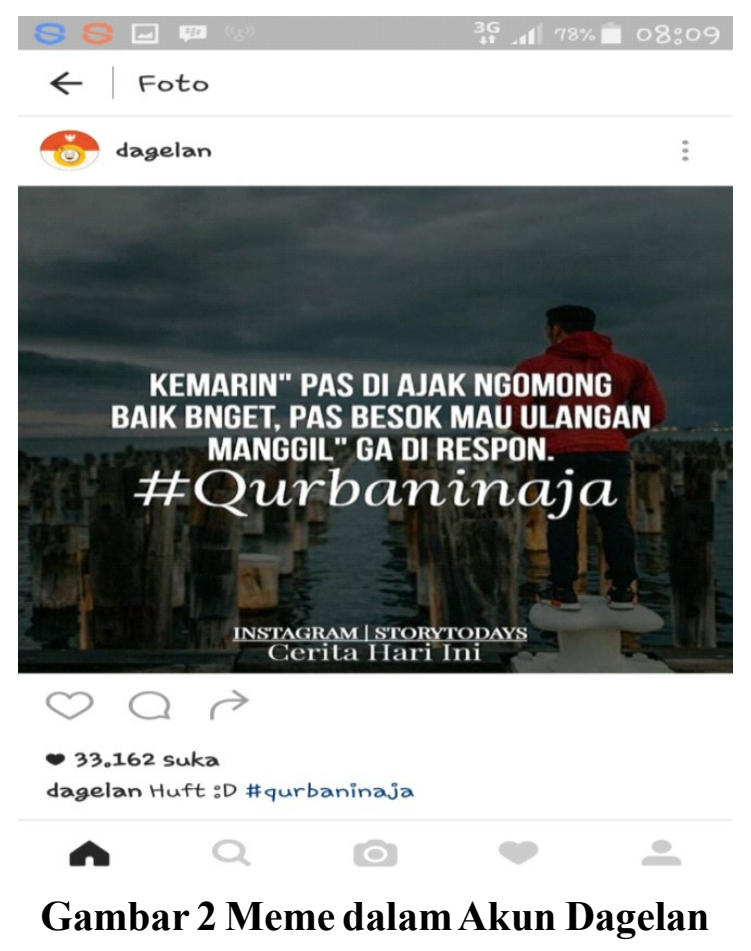

Tanda lingual yang terkandung dalam gambar (2) adalah sebagai berikut.

(1) KEMARIN "PAS DIAJAK NGOMONG BAIK BANGET, PAS BESOK MAU ULANGAN MANGGIL" GA DI RESPON

'Kemarin "ketika diajak berbicara baik sekali, besok ketika ulangan dipanggil tidak menjawab"

(2) \#Qurbaninaja

(3) e\& 33.162 suka

(4) @dagelan Huft :D \#qurbaninaja

Konteks dari kalimat pada gambar (2) dalam meme tersebut ditujukan untuk seorang teman yang pelit ketika sedang ujian. Teman seperti itu dikatakan pelit karena tidak mau membagikan hasil jawabannya saat ujian. KEMARIN "PAS DIAJAK NGOMONG BAIK BANGET, PAS BESOK MAU ULANGAN MANGGIL" GA DI RESPON "kemarin "ketika di ajak berbicara baik sekali, besok ketika ulangan dipanggil tidak ada jawaban' merupakan modus dari deklaratif. Modus deklaratif deklaratif adalah modus yang digunakan oleh pemilik akun untuk memberitakan sebuah pernyataan. Biasanya teman yang paling pintar di kelas adalah teman yang sukar untuk membagi hasil ujiannya kepada yang lain. Pernyataan ini adalah sebuah pengalaman yang pernah dirasakan oleh para pelajar.

Jenis tindakan yang digunakan dalam tuturan tersebut adalah tindak tutur langsung. Tindak tutur langsung disebabkan pemilik akun membuat meme dengan tujuan untuk memberitahukan sebuah informasi atau kejadian yang banyak dialami oleh para pelajar. Setiap individumemiliki kelebihan masing-masingyang dibawa sejak lahir. Kepintaran yang dimiliki seorang anak adalah sebuah anugerah. Tetapi tidak semua anak yang memiliki kepintaran mau berbagi dalam ujian, karena sifat individualis mereka akan muncul. Dalam keramaian mereka juga bisa jadi makhluk sosial. Mereka hanya fokus pada lembar jawaban yang ada di depan mata. Pengalaman yang pernah dialami oleh followers kembali diingatkan melalui meme oleh akun@dagelan.

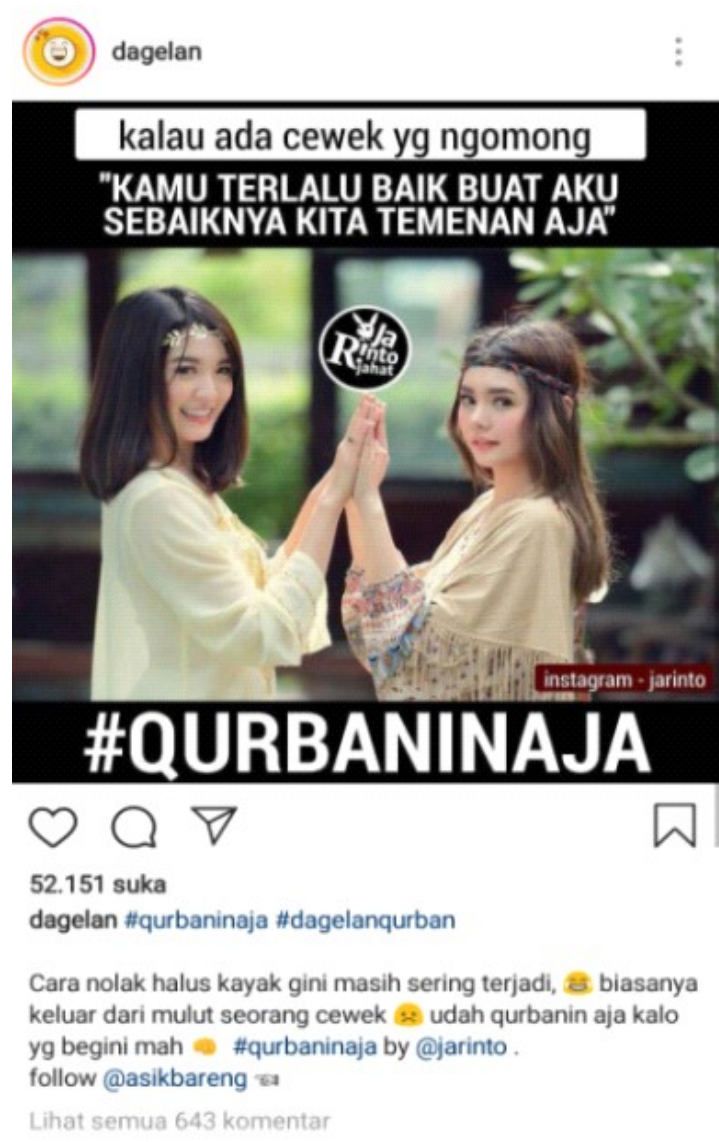

Gambar 3 Meme dalam Akun@dagelan 
Tanda lingual yang terdapat pada meme dalam gambar (3):Kalau ada cewek yang ngomong "KAMU TERLALU BAIK BUAT AKU, SEBAIKNYA KITA TEMENAN AJA". "Kalau ada perempuan yang mengatakan "kamu terlalu baik untukku, sebaiknya kita berteman saja'

(1) \#QURBANINAJA

(2) e\& 52.151 suka

(3)@dagelan\#qurbanianja\#@dagelanqurban

Tanda lingual yang ditemukan dalam meme pada gambar (3) adalah foto dua orang perempuan yang saling mengadu telapak tangan. Konteks pada meme dalam gambar (3) ditujukan untuk menyindir pengikut perempuan dari akun@dagelan yang sering mengatakan kepada para laki-laki bahwa "KAMU TERLALU BAIK BUAT AKU, SEBAIKNYA KITA TEMENAN AJA".Pernyataan tersebut biasanya digunakan untuk menolak ajakan seorang laki-laki yang ingin memulai hubungan serius dengan seorang perempuan.

Meme pada gambar (3) disukai oleh pengikut sebanyak 52.151 suka. Di bagian bawah meme ada takarir yang dituliskan sebagai penjelasan yang digunakan oleh akun @ dagelan cara menolak halus kayak gini masih sering terjadi, :'D biasanya keluar dari mulut seorang cewek. Sebelum datangnya zaman Islamiah, perempuan itu tidak berharga di mata laki-laki. Perempuan hanya dijadikan budak dan pelampiasan nafsu. Pada zaman-zaman lainnya, kaum perempuan bukanlah sesuatu yang dianggap baik bagi laki-laki.

Dengan datangnya ajaran Islamiah, kaum perempuan tidak direndahkan dan dihina lagi. Derajat kaum perempuan semakin terangkat dan sejajar dengan laki-laki. Kaum perempuan dan kaum laki-lakimenjadi sama-sama makhluk Allah yang saling berdampingan dan saling melengkapi di muka bumi. Oleh sebab itu perempuan tidak mau lagi dibodoh-bodohi oleh laki-laki.

Perempuan zaman sekarang bisa memiliki derajat yang sama dengan laki-laki.
Muqoyyidin (2013) menyebutkan bahwa di belahan dunia lain, pegiat feminis (gerakan perempuan) yang biasanya membentuk lembaga swadaya masyarakat (LSM/NGO) atau organisasi, baik mandiri ataupun berafiliasi dengan ormas tertentu atau dengan lembagalembaga pemerintah. Kegiatan yang dilakukan, pada umumnya mengambil salah satu atau beberapa dari bidang berikut ini: penelitian, penyuluhan, produksi ide, gerakan untuk kesehatan reproduksi, advokasi atas kekerasan perempuan, pelatihan-pelatihan, peningkatan pendidikan, dan lain-lain.

Meski terkadang tampak memiliki kesamaan bidang kegiatan, namun LSM feminis ternyata terdiri dari beberapa karakter, bisa dikatakan, tergantung pada 'basis ideologi' yang dianut. Ada sejumlah aliran besar feminisme yang selama ini menjadi kiblat LSM-LSM itu, yaitu: aliran feminismeliberal, feminisme kultural, feminisme radikal, dan feminisme sosialis.

Feminisme liberal, dalam perjuangannya menekankan pada hak-hak sipil kaum perempuan. Aliran ini juga memandang bahwa kaum perempuan bebas mengambil keputusan atas seksualitasnya dan hak reproduksi mereka. Perempuan yang baik tidak akan menolak secara langsung ajakan dari seorang laki-laki. Perempuan yang beralasan demikian hanya bertujuan menolak secara halus, bukan karena laki-laki tersebut benar-benar baik. Mereka hanya menyampaikan alasan agar merasa aman. Mestinya para perempuan tersebut dilupakan saja (kurbankan saja).

Seperti pada meme yang diunggah oleh akun@dagelan pada gambar (3). Modus yang dipakai dalam meme pada gambar (3) adalah deklaratif. Hal ini karena pengalaman pribadi yang pernah dirasakan oleh kaum Adam yang dituangkan ke dalam bentuk meme. Pengunggah atau pemilik akun hanya berusaha untuk memberikan informasi yang sudah diketahui banyak orang dalam media sosial. Sebuah alasan yang banyak dijadikan oleh kaum perempuan untuk menolak seorang laki-laki.

Berdasarkan modus yang digunakan meme pada gambar (3) ini jenis tindak tutur yang 
digunakan adalah tindak tutur literal. Tindak tutur literal memiliki modus esensi dan fitur yang bersesuaian. Kalimat itu bertujuan untuk menyindir kaum perempuan yang menggunakan alasan yang sudah biasa dalam media sosial atau bahkan dunia nyata. Modus literal yang digunakan memakai latar belakang foto dua orang saling menepuk tangan yang terbuka dengan mengangkat tangan. Dua orang perempuan membantu menambah kejelasan dengan menunjukkan langsung objek yang dituju.

"KAMUTERLALUBAIK BUATAKU, SEBAIKNYA KITA TEMENAN AJA". Kalimat tersebut sengaja dibuat menggunakan huruf kapital untuk memberitahukan kepada para pengikut tentang fenomena yang biasa terjadi di lingkungan masyarakat. Sebuah alasan yang baik untuk menolak ajakan seorang lakilaki. Alasan tersebut sangat berguna bagi para perempuan sebagai penolakan secara halus.

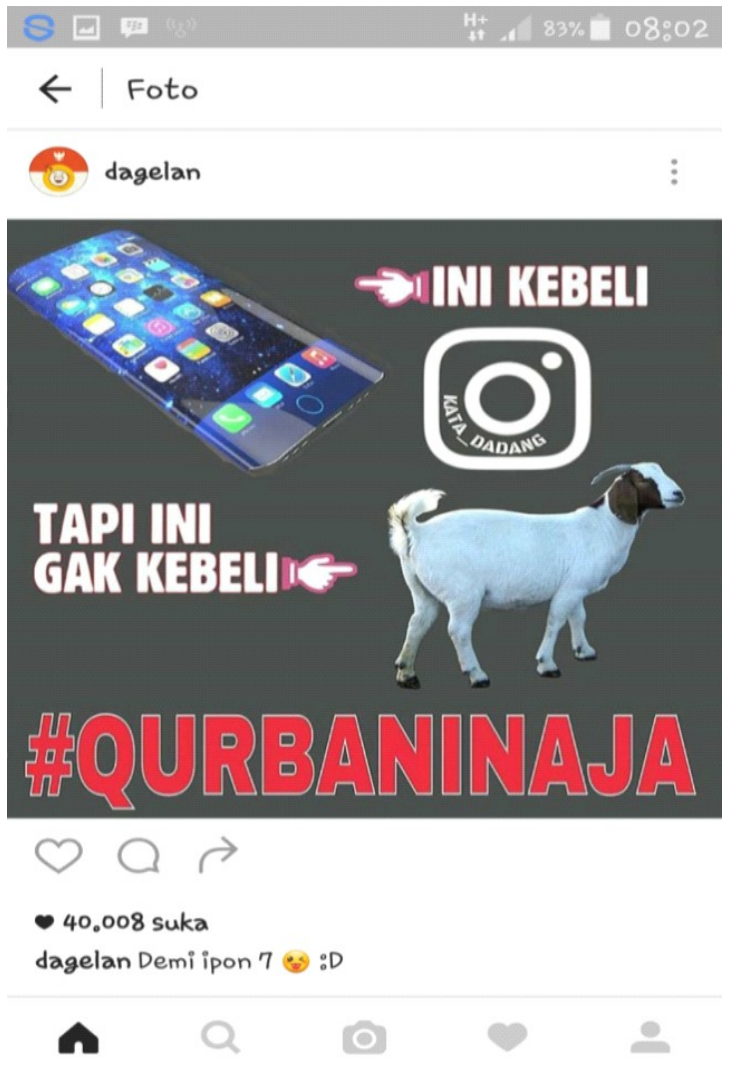

Gambar 4 Meme dalam Akun@dagelan
Tanda lingual yang terdapat pada gambar (4) adalah sebagai berikut:

(1) INI KEBELI F IPHONE 7 TAPI INI GAK KEBELIF KAMBING

(2) \#QURBANINAJA

(3) e\& 40.008 suka

(4) @dagelan Demi iphone $7: P$ :D

Berdasarkan meme pada gambar (4), penulis menemukan beberapa tanda nonlingual yang melengkapi tanda-tanda lingual dalam meme tersebut. Tanda tersebut adalah sebagai berikut.

(1) Emotikon tangan yang sedang menunjuk ke gambar ponsel

(2) Emotikon sebuah tangan yang menunjuk ke arah kambing.

(3) Lambang Instragram yang dibuat dengan warna putih dan berlatar abu-abu gelap.

Konteks meme dalam gambar (4) ditujukan untuk kaummuslim yanglebih memilih untuk membeli sebuah ponsel keluaran Iphone daripada membeli seekor kambing untuk berkurban. Telepon genggam yang ditunjuk adalah telepon genggam ekslusif yang baru dikeluarkan oleh perusahaan Apple. Kambing disimbolkan untuk perayaan qurban pada hari raya Iduladha bagi umat muslim. Postingan ini disukai sebanyak 40.008 pengikut @dagelan. Di bawah gambar ini ada sebuah takarir yang dibuat Demi iphone 7 simbol J 'demi iphone 7'

Kalimat pada gambar (4), INI KEBELI FIPHONE 7'ini sanggup dibeli, menunjuk kearah gambar Iphone 7' TAPI INI GAK $\mathrm{KEBELIF}(K A M B I N G)$ 'tapi ini tidak sanggup dibeli, menunjuk ke gambar kambing' menggunakan modus deklaratif. Kalimat tersebut menyatakan bahwa masyarakat mampu membeli benda berteknologi canggih dengan harga selangit seperti Iphone. Iphone sangat diminati oleh masyarakat dewasa ini. Seperti pernyataan yang dituliskan oleh Chandra dalam Kompas, bahwa Apple berhasil menjual 46,7 unit Iphone. Jumlah itu sama dengan perkiraan analis Wall Street 
Journal yang memproyeksikan penjualan kuartal terakhir Apple yang mencapai angka 46 juta.

Dikutip dari Okezone "Apple masih menjadi salah satu produk yang paling diminati konsumen Indonesia, dengan jumlah presentase penjualan 40 hingga 45 persen. Direktur Marketing \& Communication Erajaya Group, Djatmiko Wardoyo, mengatakan, salah satu ponsel high end yang cukup diminati di masyarakat Indonesia adalah produk-produk Apple". Banyak masyarakat dunia yang menyukai teknologi canggih berskala Internasional itu agar terlihat menarik dan berbeda dari yang lain.

Kambing yang harganya separuh dari harga Iphone tidak sanggup dibeli oleh sebagian masyarakat muslim. Penjual kambing pada perayaan Iduladha $1438 \mathrm{H}$ menyatakan bahwa ia mengalami penurunan penjualan sekitar 3040 persen dibanding tahun lalu. Salah seorang penjual, Mustafa mengatakan hal itu terjadi lantaran harga kambing yang semakin melambung. Padahal, laki-laki paruh baya itu telah turun temurun menjual kambing di Tanah Abang (Kompas.com). Jika harga kambing naik, masyarakat akan sangat mengeluh dengan harga yang membumbung tinggi. Akan tetapi, femomena yang berbeda terjadi penjulan benda berteknologi canggih, seperti Iphone. Masyarakat akan berlombalombauntuk membeli benda tersebut, walaupun harganya melambung tinggi.

Berdasarkan modusnya, kalimat dalam data (4) termasuk jenis tindak tutur literal karena tuturan pada gambar (4.1) ditemukan adanya kesesuaian antara makna kata-kata dan fiturfitur yang menyusunnya. Esensi yang terdapat pada gambar (4.1) terlihat hanya untuk memberitahukan kepada pengikut yang merasa melakukan hal yang sama dengan meme yang dibuat. Ponsel memiliki nilai beli sangat tinggi dapat dibeli oleh seseorang, sedangkan seekor kambing yang lebih murah daripada ponsel, tidak sanggup masyarakat membelinya. Esensi tersebut sejalan dengan pernyataan dan menunjukkan fitur yang sama, yaitu gambar seekor kambing dan ponsel canggih yang banyak digunakan untuk berkomunikasi dan lebih diminati.

Teknologi selalu mengalami kemajuan dari waktuke waktu. Pada era digital ini, suatu barang baru atau berteknologi canggih serta bernilai tinggi sangat diminati oleh masyarakat. Hal itu disebabkan fungsi dan kegunaan yang bermanfaat bagi kehidupan pada masa kini. Banyak yang menilai bahwa teknologi canggih disukai dan hanya mampu dibeli oleh masyarakat kelas menengah ke atas. Akan tetapi, bagi sebagian masyarakat kelas menengah ke atas merasa keberatan untuk membeli seekor kambing dengan harga yang lebih murah dari ponsel yang mereka miliki. Ada sebuah pesan yang terselip di dalam meme yang dibagikan oleh akun@dagelan.

Meme pada gambar (4) berusaha memperlihatkan lingkungan sosial masyarakat yang sudah sangat bergantung pada teknologi. INI KEBELI FIPHONE 7 'ini sanggup dibeli menunjuk ke arah Iphone 7'. Ponsel merupakan salah satu alat yang digunakan untuk berkomunikasi dengan orang lain. Akan tetapi, alat ini semakin berkembang dari waktu ke waktu. Ponsel sangat dibutuhkan oleh masyarakat saat sekarang ini. Alat itu tidak hanya untuk berkomunikasi, mencari informasi, atau sekedar mendapatkan hiburan, tetapi bisa juga menambahkan berbagai aplikasi yang sudah banyak tersedia di playstore. Lebih dari itu, memiliki ponsel canggih melambangkan status sosial pemiliknya. Oleh sebab itu banyak dari masyarakat yanglebih memilih memiliki dan memperbaharui ponsel untuk menaikan status sosial. 


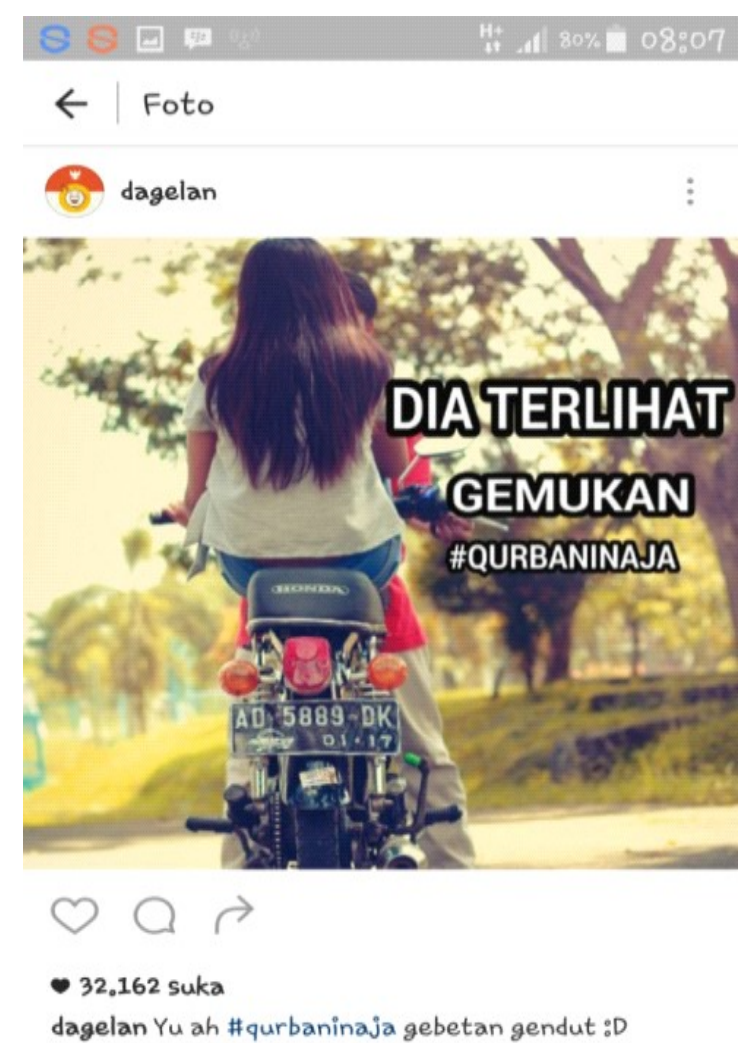

Gambar 5 Meme dalam Akun@dagelan

Beberapa tanda lingual yang terdapat dalam gambar (5):

(1)"DIA TERLIHAT GEMUKAN"

(2) \#qurbaninaja

(3) e\& 32.162 suka

(4) @ dagelan: Yu ah \#qurbaninaja gebetan gendut:D

Berdasarkan meme pada gambar (5), ditemukan tanda nonlingual untuk melengkapi tanda-tanda lingual dalam meme tersebut, yaitu gambar sepasang manusia yang saling berbocengan pada sebuah motor keluaran Honda yang diambil dari belakang.

Konteks dari meme pada gambar (5) ditujukan untuk pengikut yang memiliki gebetan gemuk atau memiliki badan yang agak berisi. Gebetan dalam KBBI daring adalah seseorang yang sedang ditaksir atau disukai. Meme pada gambar (5) merupakan foto sepasang insan manusia yang sedang mengendarai sepeda motor. Foto yang diambil membelakangi kamera menunjukkan badan pembonceng lebih besar daripada si pengendara. Sebanyak 32.162 pengikut yang menyukai meme di atas. Takarir yang terdapat di bawah gambar digunakan untuk menambah kejelasan konteks. Yu ah \#qurbaninaja gebetan gendut :D 'mari kurbankan saja gebetan gendut :D'.

Kalimat DIA TERLIHAT GEMUKAN dilontarkan setelah melihat orang lain berbeda dari biasanya karena beberapa alasan, salah satunya karena sudah lama tidak bertemu. (1) DIA TERLIHAT GEMUKAN termasuk kedalam modus deklaratif. Kalimat deklaratif biasanya digunakan oleh si pembuat meme untuk membuat sebuah pernyataan yang bertujuan untuk memberitakan sesuatu. Kalimat yang ada di dalam meme tersebut merupakan sebuah pemberitaan dengan menggunakan huruf kapital DIA TERLIHAT GEMUKAN. Kata Dia pada meme merujuk pada seorang perempuan yang sedang dibonceng oleh seorang laki-laki sebagai pengendara. Pernyataan tersebut dibuat dengan menggunakan huruf kapital. Hal ini bisa dilihat dari gambar yang diunggah, badan pengemudi tertutup oleh si pembonceng. Seorang perempuan berbaju putih yang menutupi badan si laki-laki yang menggunakan baju berwarna merah. Foto yang diunggah pada gambar (5) sejalan dengan kalimat yang dituliskan di dalamnya.

Berdasarkan modus, meme pada gambar (5) bersesuaian antara esensi dan fitur-fitur yang mendukungnya. Esensi yang ada dalam meme digunakan untuk memberitakan sesuatu perempuan yang dibonceng terlihat gendut, sementara foto yang tampak menunjukkan hal yang sama dengan pernyataan. Meme pada gambar (5) merupakan jenis tindak tutur literal. Fitur yang menyusunnya menunjukkan bahwa kata dia merupakan seorang perempuan yang terlihat besar dari seorang laki-laki yang membonceng perempuan. Hal tersebut dibuktikan dengan sebuah foto yang diambil dari belakang si perempuan.

Laki-laki sebagai pengendara tertutup oleh badan si pembonceng. Terlihat gemukan ditujukan untuk wanita yang menutupi badan si 
laki-laki. Fitur-fitur penyusun menunjukkan hal yang benar seperti tampak pada meme pada gambar (5). Ini adalah salah satu persekusi terhadap perempuan yang bertubuh gemuk.

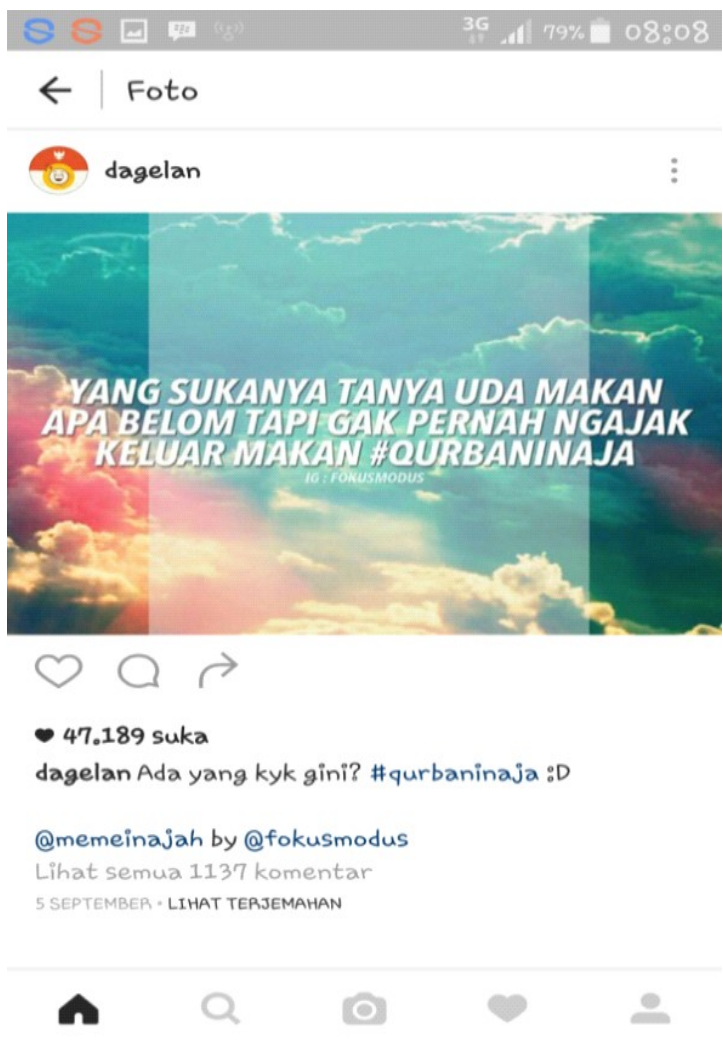

\section{Gambar 6 Meme dalam Akun dagelan}

Tanda lingual yang terdapat dalam gambar

(6) adalah sebagai berikut.

(1) YANG SUKANYA TANYA UDA MAKAN APA BELOM TAPI GAK PERNAH NGAJAK KELUAR MAKAN

'yang suka bertanya sudah makan atau belum tetapi tidak pernah mengajak untuk makan di luar'

(2) \#Qurbaninaja

(3) e\& 47.189 suka

(4)@dagelan Ada yang kaya gini? \#qurbaninaja:D

Tanda nonlingual dalam meme sebagai berikut:
(1) Penggunaan warna yang ada dalam gambar

(2) Gambar latar belakang langit dan awan yang memiliki banyak warna.

Konteks dari meme dalam gambar (6) bertujuan untuk menyindir kaum Adam yang hanya bertanya, tanpa merealisasikannya. Pertanyaan sudah makan atau belum tentu dituturkan pada jadwal makan.Pertanyaan tersebut berasal dari seorang laki-laki yang memberikan perhatian kepada orang yang dikagumi atau ditaksir. Meme pada gambar (6) disukai oleh pengikut sebanyak 47.189 orang. Latar belakang dari meme pada gambar (6) adalah foto awan yang diberi tambahan efek warna. Di bagian bawah meme ada kutipan yang dituliskan Ada yang kaya gini \#qurbaninaja :D 'ada yang seperti ini \#qurbaninaja:D'.

Modus kalimat pada gambar (6) termasuk kalimat deklaratif karena isinya bermaksud untuk memberitakan sebuah kebiasaan. Kebiasaan dari beberapa orang dalam memulai sebuah komunikasi adalah dengan bertanya sudah makan atau belum pada saat jam-jam makan. Kebiasaan ini adalah tentang basa-basi yang sudah sangat klise.

Jenis tindak tutur pada meme adalah tindak tutur tidak langsung. Tindak tutur tidak langsung disebabkan esensinya adalah memberitakan. Sementara maksud sebenarnya adalah sebuah suruhan agar si penanya mau mengajak makan. Ketika sesorang bertanya sudah makan atau belum kepada mitra tutur, jawaban dari si mitra tutur adalah belum. Si penutur hendaknya melakukan sebuah tindakan. 


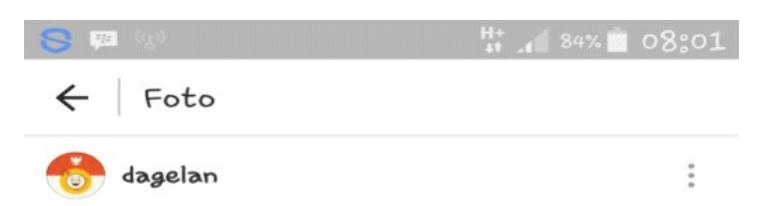

fotonya alay caption nya bijak.

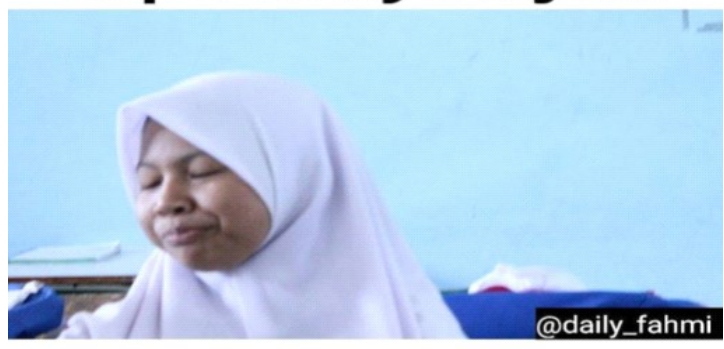

\section{\#QURBANINAJA}

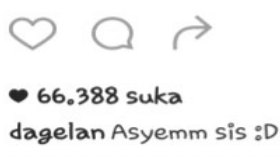

Gambar 7 Meme dalam Akun@dagelan

Tanda lingual yang terdapat dalam meme pada gambar (7) adalah sebagai berikut.

(1) Fotonya alay captionnya bijak

(2) \#QURBANINAJA

(3) e\& 66.388 suka

(4)@dagelan asyemm sis :D 'asem kak D'

Tanda nonlingual yang ada dalam meme pada gambar (7) adalah foto seorang pelajar yang menampakkan ekspresi mengejek.

Konteks dari kalimat di atas ditujukan untuk para pengikut yang selalu membubuhi takarir dengan hal yang berada di luar konteksnya. Pelajar yang sering mengunggah kutipan bijak, tetapi ekspresi wajah yang ditunjukkan pada meme memperlihatkan hal sebaliknya. Pelajar dari zaman ke zaman juga mengalami perubahan dalam hal kreatifitas. Banyak dari mereka yang menuliskan guyonanguyonan yang dapat mengocok perut. Dengan melihat fakta yang ada, ide mereka bisa muncul dan bisa dijadikan guyonan

Tuturan Fotonya alay captionnya bijak, 'fotonya alay kutipannya bijak'. Alay adalah singkatan dari anak layangan. Alay dalam KBBI daring adalah anak layangan, gaya hidup yang berlebihan untuk menarik perhatian. Anak layangan atau alay ini sama seperti komunitas lainnya yang memiliki bahasa tersendiri. Bahasa tersebut hanya dimengerti dan dipahami oleh sebagian besar komunitas. Karena bahasa alay sangat sulit dimengerti atau dibaca, orang awam tidak akan terbiasa berbahasa alay. Akan tetapi, bahasa ini dianggap oleh komunitas alay sebagai bahasa yang umum bagi mereka karena mudah dan tidak ribet.

Bahasa alay ini juga mengadopsi sedikit logat kemelayuan. Hingga saat ini bahasa ini telah dipakai untuk pesan singkat, obrolan dalam jejaring sosial, ataupun untuk penulisan sehari-hari. Karena aturan pembentukan kata bahasa alay cenderung tidak konsisten, orang awam akan membutuhkan waktu menghafal dan memahaminya.

Meme yang diunggah dalam gambar (7) memiliki modus deklaratif. Modus deklaratif adalah mudus yang dinyatakan untuk memberitakan seseuatu. Pemilik akun (a)dagelan membagikan ulang meme yang telah diunggah sebelumnya oleh daily_fahmi, untuk memberitahukan kepada pengikut yang sudah melihat unggahan dari akun@dagelan bahwa kebanyakan dari mereka membagikan foto alay dan menuliskan takarir bijak.

Meme pada gambar (7) memiliki kesesuaian antara modus dan esensinya. modus deklaratif dan esensinya untuk memberitakan sesuatu.Jenis tuturan yang ada dalam gambar (7) termasuk tindak tutur langsung. Dalam meme ini tindak tutur langsung memiliki maksud untuk memberitakan bahwa dalam kehidupan sehari-hari orang-orang biasa mengunggah foto disertai dengan takarir yang terlihat bijak. Takarir yang ditulis terkadang tidak berhubungan dengan foto terkait. Kejadian yang sudah pernah dialami bagi sebagian orang yang sering menggunakan media sosial. 

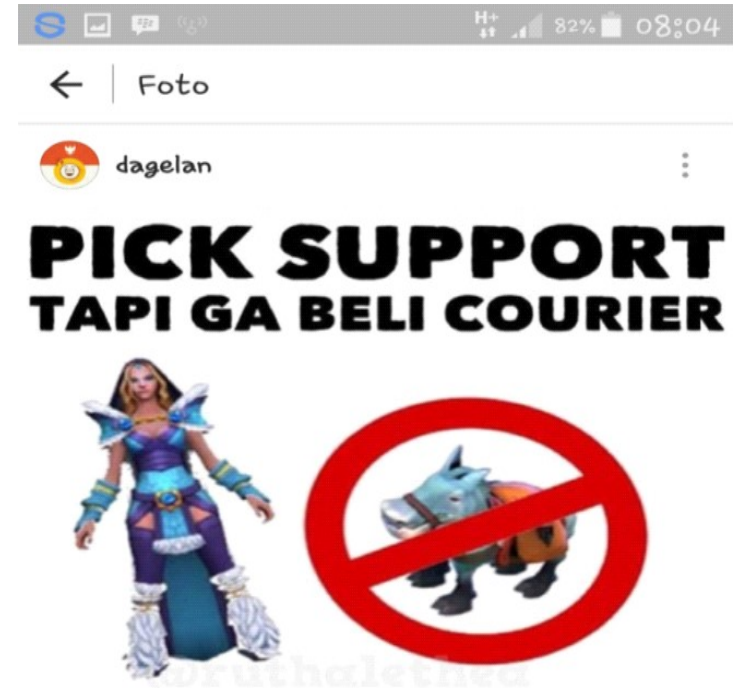

\section{\#QURBANINAJA}

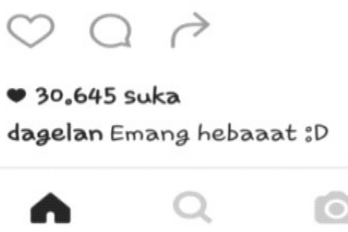

\section{Gambar 8 Meme dalam Akun@dagelan}

Tanda lingual yang terdapat dalam meme pada gambar (8) adalah sebagai berikut.

(1) PICK SUPPORT TAPI GA BELI COURIER

(2) \#QURBANINAJA

(3) e\& 30.645 suka

(4) @dagelan Emang hebaaat :D 'memang hebat:D'

Tanda nonlingual dalam gambar adalah sebagai berikut.

(1) Gambar hard support

(2) Gambar carry

Konteks dari meme pada gambar (8) adalah menyindir pengikut yang ikut memainkan dota 2, tetapi tidak ikut membeli courier. Courier sangat membantu pemain dalam permainan dota 2. Courier sangat berguna untuk mengantarkan item dari baseke hero. Berkat courier pemain tidak harus bolak-balik ambil item di base. Selain itu, courier juga bermanfaat sebagai umpan atau decoy yang efektif untuk menjebak musuh.
Meme pada gambar (8) merupakan sebuah meme dari permainan daring yang dimulai pada tahun 2013. Permainan tersebut bernama Defense of the Ancients 2 atau biasa disingkat dengan Dota 2. Permainan tersebut dirilis Valve pada Juli 2013 dan dapat dimainkan pada platform Windows, Mac OS, dan Linux. Salah satu permainan yang paling banyak dimainkan di aplikasi game (Steam) dengan jutaan pemain aktif pada setiap harinya. Permainan tersebut dimainkan oleh sebanyak 10 orang yang terbagi ke dalam 2 tim, yaitu Radiant dan Dire. Permainan dimulai dengan setiap pemain memilih 1 hero (pahlawan) dari kumpulan hero yang ada.Jumlah hero saat ini sudah lebih dari 100 hero.

Setiap hero memiliki skillset (keahlian)atau kombinasi jurus yang unik. Hero dapat diperkuat dengan berbagai cara. Setiap permainan berdurasi sekitar 20 hingga 50 menit. Tetapi pada beberapa kasus, permainan bisa berdurasi lebih dari 1 jam. Tujuan permainan ini adalah untuk mempertahankan bangunan Ancient (kuno) dari masing-masing tim. Pada saaat permainan berlangsung tim juga dibolehkan menghancurkan Ancient lawan (https://esportsnesia.com/game/dota2)

Pada gambar (8) meme tersebut menunjukkan sarkastis untuk orang yang mau menikmati saja, tetapi tidak membayar untuk kenikmatan yang diperoleh atau disebut courier. Meme pada data (8) yang bermaksud untuk memberitakan pengikut yang tidak membeli courier. Dengan demikian, meme tersebut termasuk ke dalam modus deklaratif. Gambar tersebut tidak menunjukkan ekspresi apa-apa, tetapi kalimat dan gambar yang ada dalam meme memberitahukan sesuatu yang telah biasa terjadi dalam dunia permainan daring.

Berdasarkan fungsi komunikatifnya, jenis meme dalam gambar (8) termasuk ke dalam tindak tutur tidak langsung karena maksud dan tujuan meme tersebut tidak sesuai antara modus dan esensinya. Modus dalam meme adalah deklaratif yang memberitakan sebuah kebiasaan dalam permainan dalam dunia maya. Maksud 
dan tujuannya sebenarnya adalah menyindir pemain agar membeli courier untuk bermain dota. Sindiran tersebut ditujukan kepada pengikut yang ikut bermain dota 2 yang tidak mau membeli courier.

dagelan
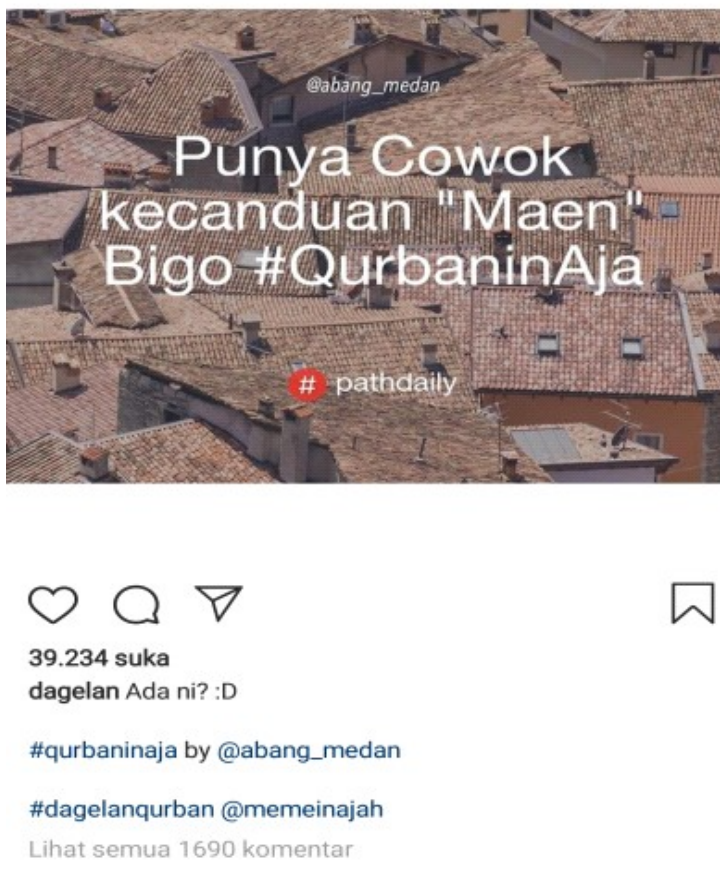

\section{Gambar 9 Meme dalam Akun@dagelan}

Tanda lingual yang terdapat pada meme dalam gambar (9):

(1) Punya Cowok Kecanduan "Maen” Bigo

(2) \#Qurbaninaja

(3)@dagelan ada ni: :D

(4) \#qurbaninaja by@abang medan

(5)\#@dagelanqurban@memeinajah

Tanda lingual yang ditemukan dalam meme pada gambar (9) adalah:

(1) Latar belakang foto atap rumah yang diambil dari langit

Konteks dalam meme pada gambar ditujukan bagi para kaum laki-laki yang sudah memiliki pasangan yang kecanduan main bigo. Bigo adalah salah satu aplikasi yang ada dalam media sosial yang mudah untuk diunggah. Bigo adalah salah satu aplikasi video yang disiarkan secara langsung dalam aplikasi android dan Ios.

Tuturan dalam meme pada gambar (9)

Punya Cowok Kecanduan "Maen" Bigo merupakan sebuah sindiran untuk kaum lakilaki yang mempunyai aplikasi bigo di dalam telepon gengamnya. Bigo merupakan sebuah aplikasi yang disiarkan secara langsung dalam media sosial. Dengan penggunaan kamera yang bagus dan memiliki akun sendiri, pengguna lain dapat melihat apa yang sedang disiarkan. Terkadang, ada anggota dari bigo yang memakai pakaian seksi agar mendapat gift dari penonton.

Tuturan pada meme dalam gambar (9) memiliki modus deklaratif karena hanya menyatakan sebuah pernyataan kepada para pengikut. Bigo dianggap sebuah aplikasi yang tidak baik oleh kebanyakan penikmat media sosial. Kata maen berarti main. Main dalam KBBI daring adalah (1) melakukan aktivitas atau kegiatan untuk menyenangkan hati (dengan menggunakan alat-alat tertentu atau tidak), (2) melakukan perbuatan untuk bersenang-senang (dengan alat tertentu atau tidak). (3) keadaan berlangsung atau mempertunjukkan (tontonan atau sebagainya).

Dalam meme pada gambar (9) arti maen adalah keadaan berlangsung yang mempertunjukkan tontonan secara langsung oleh sesama pengguna aplikasi ini. Kata maen dalam meme tersebut bermakna negatif karena tidak sedikit yang mempertontonkan daerah pribadinya ke publik. Pengguna aplikasi ini datang dari segala usia dan lapisan masyarakat. Suatu sindiran bernada satire untuk para lakilaki yang memiliki hobi janggal. Sindiran ini sekaligus ajakan bagi setiap perempuan agar menjauhi atau meninggalkan saja laki-laki berhobi janggal seperti bigo.

Jenis tindak tutur yang digunakan dalam meme pada gambar (9) adalah jenis tindak tutur tidak langsung. Tindak tutur tidak langsung karena menunjukkan modus dan esensi yang tidak sejalan. Modus yang digunakan adalah modus deklaratif, sementara esensinya adalah suruhan bagi perempuan untuk meninggalkan 
pasangan yang menyukai aplikasi tersebut. Karena dari aplikasi ini, para laki-laki dengan leluasa dapat menemukan dan melihat anggota yang menggunakan pakaian seksi.

$8 \square$ Foto
$\leftarrow$ dagelan
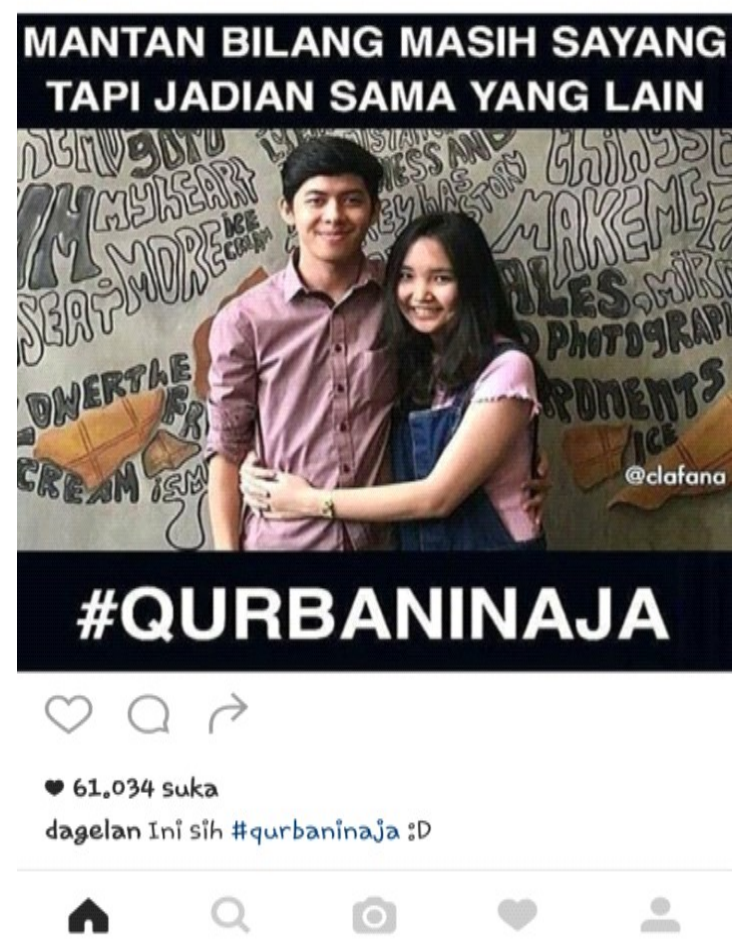

\section{Gambar 10 Meme dalam Akun @dagelan}

Tanda lingual yang terdapat dalam kalimat yang ada dalam meme pada gambar (10) sebagai berikut,

(1) MANTAN BILANG MASIH SAYANG TAPI JADIAN SAMA YANG LAIN

(2) \#QURBANINAJA

(3) e\& 61.034 suka

(4)@dagelan Ini sih \#qurbaninaja :D

Tanda nonlingual yang ada dalam meme adalah sebagai berikut.

(1) Foto sepasang kekasih yang terlihat mesra.

(2) Latar belakang foto diambil di depan dinding yang dihiasi oleh coretan-coretan.
Konteks dari tuturan meme yang ada dalam data (10) adalah menyidir mantan yang masih saling menghubungi. Mantan masih menghubungi dan masih menunjukkan rasa sayang. Rasa sayang ditunjukkan melalui komunikasiyang masih tetap terjalin. Rasa sayang yang ditunjukkan tidak sejalan dengan kenyataan. Kenyataannya sang mantan sudah menjalin hubungan baru dengan kekasih yang baru pula.

Sepasang kekasih yang mengunggah sebuah momen romantis dalam media sosial mampu membuat para para jomblo menjadi cemburu. Jika sepasang kekasih tidak lagi menjalin komunikasi, mereka sudah disebut sebagai mantan. Mantan adalah bekas seorang kekasih yang sudah tidak lagi menjalin sebuah hubungan. Meme pada data (10) bertemakan ironi yang ditujukan kepada pengikut yang memiliki mantan, tetapi masih saling sayang. Ironi yang berarti sebuah kejadian yang bertentangan dengan yang diharapkan atau yang seharusnya terjadi, tetapi sudah menjadi suratan takdir, takdir menjadi seorang mantan.

Meme yang diunggah dalam media sosial banyak mengandung sindiran. Kejadian yang biasa dialami oleh seseorang biasanya akan diunggah ke dalam media sosial dengan berbagai cara. Modus yang digunakan dalam meme pada gambar (10) adalah modus deklaratif. Deklaratif digunakan oleh pembicara atau penulis untuk membuat sebuah pernyataan sehingga isinya merupakan sebuah berita. Meme yang terdapat pada gambar (10) dibuat kreatif dengan tujuan agar sindiran parodi yang termuat di dalamnya dapat tersampaikan secara tidak langsung. Sindiran yang digunakan oleh akun@dagelan merupakan sebuah kenyataan yang terjadi dilingkungan anak muda saat ini. Anak muda yang masih labil menuangkan perasaannya melalui media sosial. Semua perasaan, seperti gundah, bahagia, dan sedih, mereka tuangkan melalui media sosial. Labil dalam Kamus Besar Bahasa Indonesia artinya goyah; tidak mantap; tidak kokoh (tentang bangunan, pendirian, dan sebagainya). Dalam hal ini sikap labil yang dimaksudkan adalah sikap 
ambigu antara keinginan hendak menerima kekasih baru dan tetap memelihara perasaan cinta kepada kekasih lama.

Berdasarkan modus yang digunakan dalam gambar (10) jenis tuturan tersebut termasuk jenis tuturan langsung karena antara modus dan esensinya bersesuaian. Modus deklaratif yang digunakan bertujuan untuk memberitahukan sebuah penyataan yang dialami oleh seorang perempuan ketika mendapat sebuah pesan singkat dari sang mantan yang sudah memiliki kekasih baru. Pesan tersebut bisa dibagikan oleh si pemilik ke akunnya untuk menjadi bahan olok-olok. Media Instagram dapat menjadi boomerang bagi sang mantan yang seperti itu. Karena jika pesan tersebut sudah dibagikan di Instagram para pengikut akan melakukan berbagai hal untuk membuat mantan melihatnya.

\section{SIMPULAN}

Meme adalah gambar atau foto yang diberi teks yang bisa menghasilkan sebuah bentuk yang baru. Meme banyak digunakan untuk mengungkapkan perasaan dalam media sosial. Meme yang ditulis merupakan tindak tutur yang berbentuk tulisan. Tindak tutur adalah sebuah tindakan yang lakukan oleh mitra tutur setelah adanya sebuah pernyataan. Berdasarkan analisis data yang telah dilakukan, penulis menyimpulkan bahwa jenis tindak tutur yang terdapat dalam meme yang mengandung \#qurbaninaja dalam akun@dagelan umumnya meliputi tindak tutur yang bermoduskan deklaratif dan interogatif. Penggunaan modus tersebut berpengaruh terhadap penggunaan tindak tutur dalam meme. Jenis tindak tutur yang ditemukan adalah tindak tutur langsung, tindak tutur tidak langsung, dan tindak tutur literal.

Dari penelitian yang telah dilakukan, peneliti menemukan hasil yang berupa sindiran dalam meme di akun dagelan. Ada 3 sindiran yang ditemukan, yaitu sindiran bernada satire, innuendo dan ironi. Sindiran yang paling banyak ditemukan adalah sindiran yang berbentuk satire karena maksud yang diutarakan oleh pemilik akun untuk menertawakan pengikut yang melakukan hal yang dimaksudkan dalam meme.

Dari kesepuluh meme yang diteliti satu meme menggunakan sindiran bernada innuendo pada gambar (2). Karena penggunaan gaya bahasa sindiran yang tidak langsung mengatakan ga direspon 'tidak ada tanggapan' tetapi didahului dengan pengungkapan kata baik banget 'baik sekali' . Dua bentuk sindiran ironi yang ada dalam meme pada gambar (3) dan gambar (10) berupa sindiran halus yang maknanya bertentangan dengan makna yang sebenarnya. Dan 7 bentuk sindiran lain yaitu satire yang berada dalam meme pada gambar $(1,4,5,6,7,8,9)$. Sindiran yang bermakna satire dalam meme digunakan untuk memperhalus sindiran dengan tawaan dan olok-olok agar pengikut tidak merasa tersinggung. Sindiran yang terkandung dalam meme ditujukan bagi pengikut (followers) dalam akun dagelan di Instagram.

\section{DAFTAR PUSTAKA}

Afriyanti, Desi. 2015. "Kajian Pragmatik Tindak Tutur Pengajar Bimbel Ganesha Operation (GO) Sumatera Barat dalam Status Facebook tentang Penyambutan Tahun Baru 2014". Tesis: Universitas Andalas Padang: Tidak diterbitkan.

Alwi, dkk. 2003. Tata Bahasa Baku Bahasa Indonesia (Edisi ketiga). Jakarta: Balai Pustaka.

Hutagaol, Boi. (2018). Apa itu Dota 2?. Diunduh tanggal 20 Juni 2019. Dari https:/ /esportsnesia.com/game/dota2/apa-itudota-2/

Jabbar, Ahmad Kamal Abdul. 2016. "Tren meme dan ruang kebebasan dalam $F a n$ Page Meme Comic Indonesia". www.dglib.uns.ac.id. Diunduh tanggal 14 Juni 2017. 
Kamus Besar Bahasa Indonesia daring.

Keraf. Gorys. 2007. Diksi dan Gaya Bahasa. Jakarta: PT. Gramedia

Mahendra, Ikhsan Tila. (2017). "Peran Media Sosial Instagram dalam Pembentukan Kepribadian Remaja Usia 12--17 Tahun di Kelurahan Kebalen Kecamatan Babelan Kabupaten Bekasi”. Skripsi. Diunduh tanggal 18 Agustus 2018. http:// repository.uinjkt.ac.id/dspace/bitstream/ $123456789 / 34490 / 1 /$ Ikhsan\%20Tila\%20Mahendra-FITK.

Moleong, Lexy J. 2010. Metedologi Penelitian Kualitatif. Edisi revisi. Bandung: PT Remaja Rosdakarya.

Muqoyyidin, Andik Wahyun. 2013. "Wacana Kesetaraan Gender: Pemikiran Islam Kontemporer Tentang Gerakan Feminisme Islam”. Volume. 13 Nomor 2, Desember 2013 Hal 491 - 512. Jurnal Al-Ulum. Diunduh tanggal 26 April 2020 pukul 09.43 WIB.

Nugraha, dkk. 2015. "Fenomena Meme Di Media Sosial: Studi Etnografi Virtual Posting Meme Pada Pengguna Media Sosial Instagram". Vol. 14, No 3, Desember 2015. Jurnal Sosioteknologi. Diunduh tanggal 27 April 2020 Pukul 11.15 WIB

Okezone. (2015). Produk Apple Jadi Primadona di Indonesia. Diunduh Tanggal 28 April 2020. Pukul 13.16 WIB dari: https://techno.okezone.com/ read/2015/09/15/207/1214734/produkapple-jadi-primadona-di-indonesia

Searle, John R. 1969. Speech Acts An Essay in the Philosophy of Language. London:Cambridge University.
Sudaryanto. 1993. Metode dan Aneka Teknik Analisis Bahasa. Yogyakarta: Duta Wacana University Press.

Wijana, I. Dewa Putu. 1996. Dasar-dasar Pragmatik. Yogyakarta: Andi 